
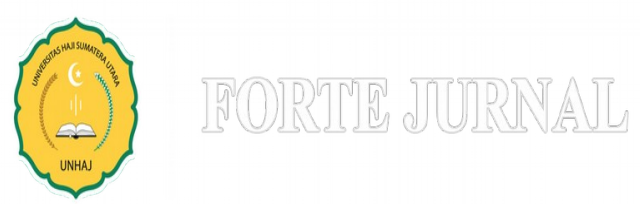

Hal $19-25$

\title{
PERBANDINGAN AKTIVITAS ANTIBAKTERI EKSTRAK ETANOL BIJI PEPAYA (Carica papaya L.) TERHADAP BAKTERI Escherichia coli DAN Staphylococcus aureus
}

\author{
Ovalina Sylvia Br. Ginting \\ Universitas Haji Sumatera Utara, Medan, Indonesia \\ *E-mail: ovalinasylviabr.ginting@gmail.com
}

\begin{abstract}
Abstrak
Bakteri dapat menjadi penyebab utama berbagai gangguan kesehatan, seperti gangguan pencernaan, diare dan penyakit kulit. Biji papaya pepaya (Carica papaya L.) telah terbukti secara empiris dapat mengatasi berbagai gangguan tersebut. Tujuan penelitian ini adalah untuk mengetahui perbandingan aktivitas antibakteri ekstrak etanol biji pepaya (Carica papaya L.) terhadap bakteri Escherichia coli (ATCC 10536) dan bakteri Staphylococcus aureus (ATCC 29737). Pembuatan ekstrak dilakukan dengan cara maserasi menggunakan pelarut etanol $80 \%$. Skrining fitokimia dilakukan terhadap simplisia dan ekstrak biji pepaya. Metode pengujian yang dilakukan dengan menggunakan metode difusi agar dengan punch hole. Hasil skrining fitokimia pada ekstrak etanol menunjukkan bahwa ekstrak dari biji pepaya mengandung flavonoid, glikosida, saponin, tanin dan alkaloid. Perbandingan aktivitas antibakteri pada ekstrak etanol biji pepaya pada konsentrasi $500 \mathrm{mg} / \mathrm{mL}$ menunjukkan lebih efektif untuk menghambat perkembangan bakteri Staphylococcus aureus dengan daya hambat sebesar 16,5 mm dibandingkan terhadap bakteri Escherichia coli yang daya hambatnya hanya sebesar 15,7 mm. Kata Kunci: antibakteri, biji pepaya, ekstrak etanol, Escherichia coli, Staphylococcus aureus
\end{abstract}

\begin{abstract}
Bacteria can be a major cause of various health problems, such as digestive disorders, diarrhea and skin diseases. Papaya papaya seeds (Carica papaya L.) have been empirically proven to overcome these various disorders. The purpose of this study was to compare the antibacterial activity of ethanol extract of papaya seeds (Carica papaya L.) against Escherichia coli bacteria (ATCC 10536) and Staphylococcus aureus bacteria (ATCC 29737). The extract was made by maceration using $80 \%$ ethanol. Phytochemical screening was carried out on simplicia and papaya seed extract. The test method is carried out using the agar diffusion method with a punch hole. The results of phytochemical screening on ethanol extract showed that extracts from papaya seeds contained flavonoids, glycosides, saponins, tannins and alkaloids. Comparison of antibacterial activity in the ethanol extract of papaya seeds at a concentration of $500 \mathrm{mg} / \mathrm{mL}$ showed more effective inhibition of the development of Staphylococcus aureus bacteria with a inhibition of 16.5 mm compared to Escherichia coli bacteria whose inhibition was only $15.7 \mathrm{~mm}$.
\end{abstract}

Keywords: antibacterial, papaya seeds, ethanol extract, Escherichia coli, Staphylococcus aureus 


\section{Pendahuluan}

Escherichia coli adalah bakteri gram negatif, berbentuk batang coklat, berderet seperti rantai. Escherichia coli dapat menyebabkan penyakit seperti diare, saluran kemih, pneumonia, meninggitis pada bayi yang baru lahir dan infeksi luka. Staphylococcus aureus merupakan bakteri gram positif, aerob dan anaerobfakultatif berbentuk bola atau kokus berkelompok tidak teratur, diameter $0,8-1,0 \mu \mathrm{m}$, tidak membentuk spora atau tidak bergerak, koloni berwarna kuning. Bakteri ini terdapat pada kulit, selaput lendir, bisul dan luka. Dapat menimbulkan penyakit melalui kemampuanya berkembang biak dan menyebar luas dalam jaringan (Pelczar dan Chan, 1988; Karsinah et.al., 1994; Jawetz et al., 2001).

Pepaya (Carica papaya L.) merupakan tanaman yang berasal dari Amerika tropis. Pusat penyebaran tanaman ini diduga berada di daerah sekitar Meksiko bagian selatan dan Nikaragua. Pelayar-pelayar bangsa Portugis di abad ke-16, tanaman ini menyebar ke berbagai benua dan negara, termasuk benua Afrika dan Asia serta negara India. Tanaman ini menyebar ke berbagai negara tropis lainnya, termasuk Indonesia dan pulau-pulau di Lautan di abad ke-17 (Baga, 2000).

Kandungan kimia dalam buah pepaya (Carica papaya L.) adalah papain yang terdapat dalam getah buah pepaya, yaitu suatu senyawa yang dapat mempercoklat daya cerna pepsin sehingga pencernaan lebih sempurna. Kandungan senyawa lain dalam biji pepaya yang memiliki potensi antibakteri, antara lain tanin, saponin, triterpenoid dan flavonoid (Yin-Fang dan Cheng-Jun, 2002; Miean dan Suhaila, 2000).

Berdasarkan uraian di atas, maka dilakukan penelitian aktivitas antibakteri dari ekstrak etanol biji pepaya terhadap bakteri Escherichia coli dan bakteri Staphylococcus aureus untuk melihat efektivitas antibakteri ekstrak biji papaya terhadap kedua jenis bakteri tersebut. Pengujian aktivitas antibakteri dilakukan secara mikrobiologi dengan metode difusi agar menggunakan punch hole. Pengamatan dilakukan dengan mengukur diameter zona hambat pertumbuhan bakteri menggunakan jangka sorong (Pelczar dan Chan, 1988; Robinson, 1995).

\section{Metode Penelitian \\ Tempat Penelitian}

Penelitian ini dilakukan di Laboratorium Fitokimia dan Mikrobiologi Fakultas Farmasi, Universitas Sumatera Utara.

\section{Alat dan Bahan}

Alat yang digunakan adalah alat-alat gelas laboratorium, botol kaca maserasi, freeze dryer (Modulio), inkubator (Memmert), jangka sorong, jarum ose, laminar airflow cabinet LAF (Astec HLF 1200 L), mikro pipet (Eppendorf), neraca analitik (Mettler AE 200), oven (Gallenkamp), pencadang logam dan rotary evaporator (Haake D).

Bahan yang digunakan dalam penelitian ini adalah serbuk simplisia dari biji pepaya, aquadest, etanol, DMSO, aquabidest steril, bakteri Escherichia coli, media nutrient agar (NA) dan media nutrient broth (NB) dan pereaksi untuk uji skrining.

\section{Penyiapan Sampel}

Biji pepaya (Caricae semen) yang digunakan sebagai sampel diperoleh dari buah pepaya yang sudah matang. Biji pepaya yang diperoleh dibersihkan dengan cara dicuci diair mengalir, lalu ditiriskan, dikeringkan pada suhu $40^{\circ} \mathrm{C}$ terlindung dari sinar matahari langsung, lalu dihaluskan dan diayak hingga diperoleh serbuk simplisia (Depkes RI, $1995)^{\mathrm{b}}$. 


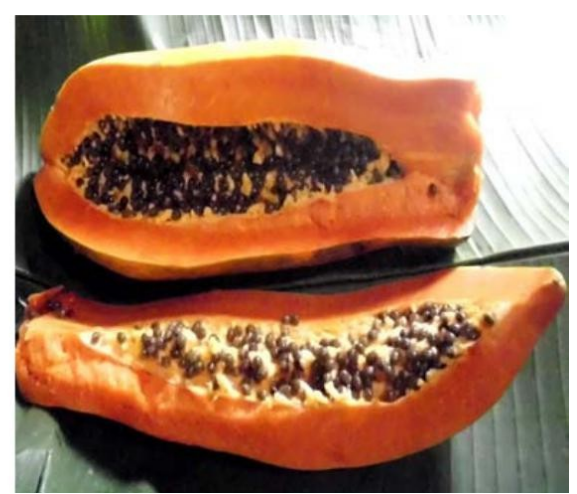

Gambar 1. Buah pepaya

\section{Skrining Fitokimia}

Skrining fitokimia serbuk simplisia biji pepaya meliputi, pemeriksaan senyawa alkaloid, glikosida, saponin, flavonoid, antrakuinon dan tannin (Ginting, 2013).

\section{Pembuatan Ekstrak Biji Pepaya}

Sebanyak $350 \mathrm{~g}$ serbuk simplisia biji pepaya dimasukkan ke dalam wadah gelas berwarna gelap lalu dimaserasi dengan 7,5 bagian pelarut etanol $80 \%$ selama 5 hari terlindung dari cahaya matahari sambil sering diaduk, setelah 5 hari hasil maserasi disaring dan diperas dengan kertas saring lalu ampasnya ditambahkan cairan penyari secukupnya sehingga diperoleh seluruh maserat sebanyak 3,5 liter. Kemudian maserat didiamkan selama 2 hari dan dienap tuangkan. Maserat diuapkan dengan bantuan alat penguap rotary evaporator pada temperatur tidak lebih dari $70^{\circ} \mathrm{C}$ dan di freeze dryer sampai diperoleh ekstrak kental (Depkes RI, 1979).

\section{Sterilisasi Alat dan Bahan}

Alat dan bahan untuk pemeriksaan mikrobiologi harus disterilkan terlebih dahulu sebelum dipakai. Alat-alat gelas disterilkan didalam oven pada suhu $170^{\circ} \mathrm{C}$ selama 1 jam, sedangkan media disterilkan di dalam autoklaf pada suhu $121^{\circ} \mathrm{C}$ selama 15 menit serta jarum ose dan pinset disterilkan dengan menggunakan lampu Bunsen (Difco, 1977; Lay, 1994).

\section{Pembuatan Stok Kultur dan Inokulum Bakteri}

Koloni bakteri Escherichia coli diambil dengan jarum ose steril, lalu diinokulasikan pada permukaan media nutrient agar (NA) miring dengan cara menggores, kemudian diinkubasi pada suhu $37 \pm 1{ }^{\circ} \mathrm{C}$ selama 24 jam. Selanjutnya koloni dari stok kultur diambil menggunakan jarum ose steril dan disuspensikan ke dalam $10 \mathrm{~mL}$ larutan nutrient broth (NB) steril lalu diinkubasi pada suhu $37 \pm 1{ }^{\circ} \mathrm{C}$ sampai diperoleh transmitan $25 \%$ menggunakan spektrofotometer visible pada panjang gelombang $580 \mathrm{~nm}$. Hal yang sama juga dilakukan terhadap bakteri Staphylococcus aureus (Depkes RI, $1995)^{\mathrm{a}}$.

\section{Pembuatan Larutan Uji Ekstrak Biji Pepaya}

Sebanyak $1 \mathrm{~g}$ ekstrak etanol biji pepaya ditimbang, lalu ditambahkan DMSO 1 $\mathrm{mL}$ dan diaduk hingga larut, setelah itu ditambahkan aquabidest steril hingga volume total $2 \mathrm{~mL}$ lalu dihomogenkan, maka didapat konsentrasi $500 \mathrm{mg} / \mathrm{mL}$, kemudian dibuat pengenceran dengan konsentrasi 400, 300, 200, 100 dan 50 mg/mL (Ginting, 2017). 


\section{Pengujian Aktivitas Antibakteri Terhadap Bakteri Escherichia coli dan Bakteri Staphylococcus aureus}

Sebanyak $0,1 \mathrm{~mL}$ inokulum (masing-masing dari Bakteri Escherichia coli dan Bakteri Staphylococcus aureus) dimasukkan ke dalam masing-masing cawan petri steril, setelah itu dituangkan media NA sebanyak $20 \mathrm{~mL}$ dengan suhu $45-50^{\circ} \mathrm{C}$, lalu dihomogenkan. Pada media yang telah memadat dibuat lubang dengan pencadang logam kemudian dipipet $0,1 \mathrm{~mL}$ larutan uji ekstrak etanol biji pepaya dengan berbagai konsentrasi yang telah disiapkan sebelumnya, lalu diinkubasi di dalam inkubator pada suhu $37 \pm 1{ }^{\circ} \mathrm{C}$ selama 18-24 jam, lalu diukur diameter daerah hambatan (zona jernih) pertumbuhan bakteri disekitar lubang dengan menggunakan jangka sorong (Ginting, 2017).

\section{Hasil Dan Diskusi}

\section{Hasil Skrining Fitokimia}

Berdasarkan hasil penelitian Tambunan et.al., (2018), hasil skrining fitokimia dari simplisia dan ekstrak etanol biji pepaya dapat dilihat pada tabel 1 di bawah ini:

Tabel 1. Perbandingan hasil skrining fitokimia

\begin{tabular}{clcc} 
& \multicolumn{1}{c}{ Parameter } & \multicolumn{2}{c}{ Biji Pepaya } \\
\cline { 3 - 4 } No. & & Simplisia & Ekstrak \\
\hline 1. & Steroid/Terpenoida & + & - \\
2. & Glikosida & - & - \\
3. & Flavonoida & + & + \\
4. & Saponin & + & + \\
5. & Tanin & + & + \\
6. & Alkaloida & + & + \\
7. & Antrakuinon & - & - \\
\hline
\end{tabular}

\section{Keterangan:}

$+\quad$ : Mengandung senyawa yang diperiksa

- $\quad$ : Tidak mengandung senyawa yang diperiksa

Berdasarkan tabel di atas dapat dilihat bahwa simplisia dan ekatrak etanol biji pepaya positif mengandung senyawa flavonoida, saponin, tanin dan alkaloida. Senyawa flavonoida dan tanin memiliki efek sebagai antibakteri. Senyawa flavonoida yang memiliki gugus $-\mathrm{OH}$ umumnya dimanfaatkan sebagai antiseptik karena dapat merusak dinding sel bakteri. Sedangkan tanin bekerja dalam penyerapan cairan sehingga dapat menyebabkan dinding sel bakteri menjadi kering dan pecah. Kedua senyawa ini sangat berperan dalam mendukung pemanfaatkan biji pepaya sebagai antibakteri (Markham, 1988; Miean, 2000; Pratiwi, 2008; Sukadana et.al., 2008).

\section{Hasil Uji Aktivitas Antibakteri Ekstrak Etanol Biji Pepaya Terhadap Bakteri Escherichia coli dan Bakteri Staphylococcus aureus}

Hasil uji aktivitas antibakteri menunjukkan bahwa ekstrak etanol biji pepaya dapat menghambat pertumbuhan bakteri Escherichia coli dan bakteri Staphylococcus aureus. Hasil pengukuran diameter daerah hambat ekstrak etanol dari biji pepaya dapat dilihat pada tabel 2 sebagai berikut: 
Tabel 2. Hasil uji aktivitas antibakteri ekstrak etanol biji pepaya terhadap bakteri Escherichia coli dan bakteri Staphylococcus aureus

\begin{tabular}{ccc}
\hline \multirow{2}{*}{ Konsentrasi ekstrak $(\mathbf{m g} / \mathbf{m L})$} & \multicolumn{2}{c}{ Diameter hambat pertumbuhan bakteri $(\mathbf{m m}) *$} \\
\cline { 2 - 3 } & Escherichia coli & Staphylococcus aureus \\
\hline 500 & 15,7 & 16,5 \\
400 & 13,9 & 13,5 \\
300 & 12,8 & 12,9 \\
200 & 12,1 & 11,8 \\
100 & 11,2 & 11,3 \\
50 & - & - \\
Blanko & - & - \\
\hline
\end{tabular}

Keterangan:

* : Hasil rata-rata tiga kali pengukuran

- : Tidak ada hambatan

Berdasarkan tabel di atas dapat dilihat bahwa ekstrak etanol biji pepaya lebih efektif dalam menghambat pertumbuhan bakteri Staphylococcus aureus dibandingkan dengan bakteri Escherichia coli. Namun, perbandingan diameter daya hambat terhadap kedua jenis bakteri ini, tidaklah begitu signifikan dan keduanya telah memenuhi syarat penggunaan dalam pengobatan yaitu daya hambat minimal sebesar $14 \mathrm{~mm}$ dengan konsentrasi $500 \mathrm{mg} / \mathrm{mL}$. Untuk melihat lebih jelas luas daerah hambat pada penelitian ini dapat dilihat pada gambar 2 di bawah ini:
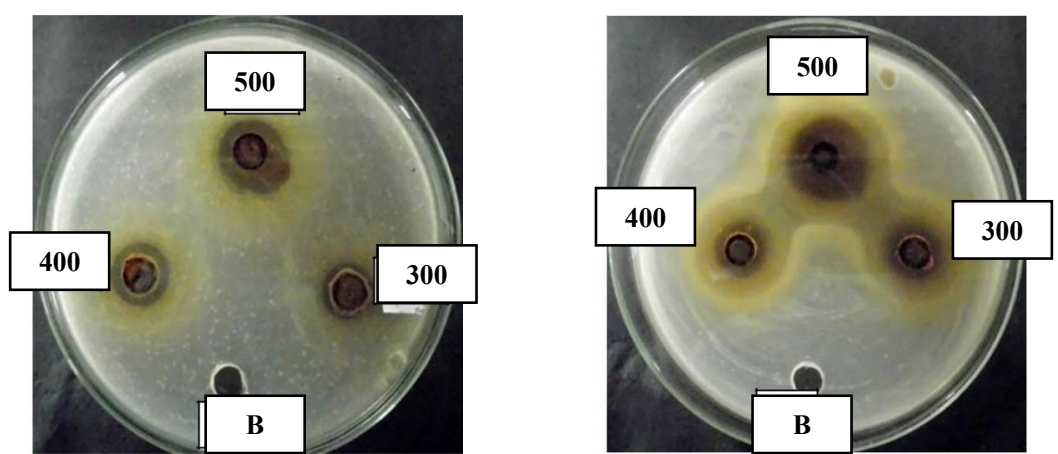

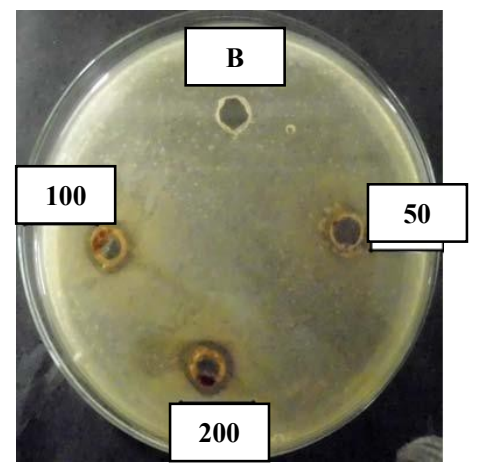

Escherichia coli

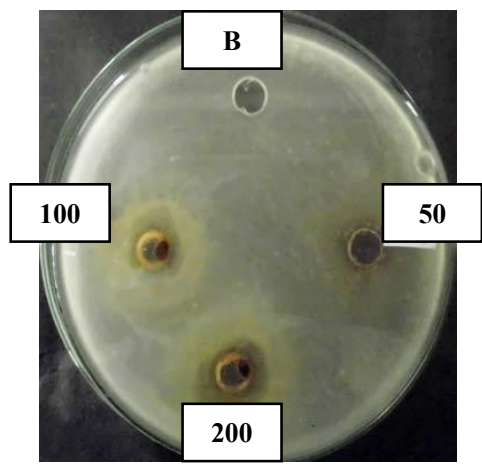

Staphylococcus aureus

Gambar 2. Pengujian ekstrak etanol biji pepaya terhadap bakteri Escherichia coli dan bakteri Staphylococcus aureus.

Keterangan:

B

: Blanko (DMSO : aquabidest steril $=1: 1)$ 
50, 100, 200, 300, 400, $500 \quad$ : Konsentrasi larutan uji $(\mathrm{mg} / \mathrm{mL})$

Pada gambar 2 di atas dapat dilihat bahwa ekstrak etanol biji pepaya menunjukkan area hambat yang lebih jelas dengan diameter yang lebih luas terhadap bakteri Staphylococcus aureus dibandingkan dengan terhadap bakteri Escherichia coli. Hal ini menunjukkan bahwa ekstrak etanol biji pepaya lebih baik dalam menghambat pertumbuhan bakteri Staphylococcus aureus dibandingkan dengan bakteri Escherichia coli pada konsentrasi yang sama.

\section{Kesimpulan}

Ekstrak etanol biji pepaya lebih efektif dalam menghambat pertumbuhan bakteri Staphylococcus aureus sebesar 16,5 mm dibandingkan terhadap bakteri Escherichia coli yang daya hambatnya hanya sebesar $15,7 \mathrm{~mm}$ pada konsentrasi pada konsentrasi $500 \mathrm{mg} /$ $\mathrm{mL}$. Dalam kehidupan sehari-hari ekstrak biji pepaya telah terbukti aman dikonsumsi untuk membantu mengatasi penyakit diare dan gangguan pencernaan lainnya. Sumber yang banyak tersedia di alam serta dapat dibudidayakan dengan mudah menjadi salah satu keunggulan pemanfaatan biji pepaya sebagai obat tradisional dalam mengatasi berbagai penyakit. Namun, perlu dilakukan penelitian lebih lanjut untuk mengetahui pengaruh penggunaan dan efek samping ekstrak biji pepaya terhadap fungsi faal tubuh.

\section{Referensi}

Baga, K.M. (2000). Bertanam Pepaya. Jakarta: Penebar Swadaya. Halaman 1-30.

Depkes. (1979). Farmakope Indonesia. Edisi III. Jakarta: Depkes RI. Halaman 9, 33, $659,748$.

Depkes. (1995) a. Farmakope Indonesia. Edisi IV. Jakarta: Departemen Kesehatan RI. Halaman 891-898, 1154.

Depkes. (1995) ${ }^{\mathrm{b}}$. Materia Medika Indonesia. Jilid VI. Jakarta: Departemen Kesehatan Republik Indonesia. Halaman 50-54, 300-304.

Difco, L. (1977). Difco Manual of Dehydrated Culture Media and Reagents for Microbiology and Clinical Laboratory Procedures. Ninth edition. Detroit Michigan: Difco Laboratories. Halaman 32-33, 64.

Ginting, O.S. (2013). Pengujian Ekstrak $n$-Heksana dan Etanol terhadap Aktivitas Antibakteri Biji Pepaya (Carica Papaya L.) Dari Dua Varietas. Repository USU.

Ginting, O.S. (2017). Perbandingan Aktivitas Antibakteri Ekstrak Etanol Biji Pepaya (Carica papaya L.) Dari Dua Varietas Terhadap Bakteri Escherichia coli. Jurnal STIKNA, Vol. 1, No.2 (2017), 183-188.

Jawetz E, Melnick GE, and Adelberg CA. (2001). Mikrobiologi Kedokteran. Edisi I. Penerjemah: Bagian Mikrobiologi Kedokteran Universitas Airlangga. Surabaya: Penerbit Salemba Medika. Halaman 211-249.

Karsinah, Lucky, Suharti, Mardiastuti. (1994). Batang Negatif Gram, Escherichia coli. Dalam Buku Mikrobiologi Kedokteran Universitas Indonesia. Edisi Revisi Th.1994. Jakarta: Binapura Aksara. Halaman 168-173.

Lay, B.W. (1994). Analisis Mikroba di Laboratorium. Jakarta: PT. Raja Grafindo Persada. Halaman 109.

Markham, K.R. (1988). Cara Mengidentifikasi Flavonoida. Bandung: Penerbit ITB. Halaman 23-47. 
Miean, K.H. dan Suhaila, M. (2000). Flavonoid (Myricetin, Quercetin, Kaempferol, Luteolin, and Apigenin) Content of Edible Tropical Plants. Pdf.

Pelczar, M, dan Chan, E.C.S. (1988). Elements of Microbiology. New York: McGrawHill Companies Inc. Terjemahan: Ratna Siri Hadioetomo, Teja Imas, Sutarmi Tjitosomo, Sri Lestari Angka. Dasar-Dasar Mikrobiologi. Jakarta: Penerbit UI-Press. Halaman 117, 145-148.

Pratiwi, S.T. (2008). Mikrobiologi Farmasi. Yogyakarta: Erlangga. Halaman 106-118.

Robinson, T. (1995). The Organic Constituents of Hight Plant. Fourth Edition. New York: University of Massachusetts. Terjemahan: Kosasih Padmawinata. Kandungan Organik Tumbuhan Tinggi. Edisi VI. Bandung: Penerbit ITB. Halaman 71, 191-193.

Sukadana, I.M., Santi, S.R., Juliarti, N.K. (2008). Antibakteri Senyawa Golongan Triterpenoid Dari Biji Pepaya (Carica Papaya L.). Journal of Pharmaceutical Chemistry. 2(1): 15-18.

Tambunan, M.L., Sitompul, E., dan Ginting, O.S. (2018). Perbandingan Aktivitas Antibakteri Ekstrak Etanol dan Ekstrak $n$-Heksana Biji Pepaya (Carica papaya L.) Terhadap Bakteri Escherichia coli. Jurnal STIKNA, Vol. 2, No.1 (2018), 16.

Yin, F. dan Liu, C.J. (2002). Terapi Buah. Jakarta: Prestasi Pustaka. Halaman 146-147. 